\title{
Features of Techno-Economic Calculation of Commercial Cooling Chambers
}

\author{
M. Khmelniuk, D. Vazhinskyi, O. Ostapenko \\ Odessa National Academy of Food Technologies, 112 Kanatna str., Odesa, 65039, Ukraine
}

The article touches upon the design and calculation of trade objects refrigerating chambers. The influence of the cost of various groups of components and equipment on the final cost of the camera is analyzed. The influence of such factors as noise, fire safety and location of equipment during operation and installation is described. Recommendations are given on the choice of components in the design.

Keywords: Cooling Chamber; Techno-economic Calculation; Shop Building

\section{Особливості техніко-економічних розрахунків холодильних камер об'єктів торгівлі}

Хмельнюк М. Г., Важинський Д. І., Остапенко О.В.

Одеська національна академія харчових технологій, вул. Канатна, 112, Одеса, 65039, Україна

\begin{abstract}
Стаття описує особливості розрахунку і проектування холодильних камер об'єктів торгівлі. Аналізується вплив вартості різних груп комплектуючих і обладнання на кінцеву собівартість камери. Має місие опис впливу таких факторів як шуми, пожежна безпека і розташування обладнання на підсумкові затрати при монтажі і експлуатації. Дані рекомендації по вибору комплектуючих при проектуванні.
\end{abstract}

Ключові слова: Холодильна камера; Техніко-економічний розрахунок; Магазинобудування

DOI: $\underline{\text { http://dx.doi.org/10.15673/ret.v53i2.590 }}$

(C) The Author(s) 2017. This article is an open access publication

This work is licensed under the Creative Commons Attribution 4.0 International License (CC BY)

http://creativecommons.org/licenses/by/4.0/

\section{Introduction}

Insulation materials hold a special place in the design of refrigerating chambers. In commercial refrigeration, polyurethane foam panels have become extremely popular. This is due, on the one hand, to the simplicity of installation, the chamber in question can be assembled by a team of two people within one working day, and by the ease of operation in the future, the panels are well cleaned and retain their attractive appearance for a long time. The thickness of the panels is represented by the following values: $80 \mathrm{~mm}, 100 \mathrm{~mm}, 120 \mathrm{~mm}, 140 \mathrm{~mm}$. For the commercial applications, there are significant fluctuations in the heat load, and, as a rule, nothing is said about this in the technical assignment. The main causes of significant heat loads are interruptions, and logistics, the goods do not always come with the necessary temperature. Another important factor is the work of the staff. Often, the chamber can be opened for several hours, which is caused by a large turnover of goods on holidays. Another serious problem is the procedure for the acceptance of goods, which can often take a considerable time, respectively, the product is significantly heated. All of the above said, that commercial refrigerating chambers can not be fully classified as storage chambers. For reliable operation of the compressor and maintaining the required temperature in the cooled volume, additional cooling capacity must be applied. Respectively, the thermal calculation, also must take into account the heat inflow from the products.

Table 1 shows the result of the thermal calculation of a low-temperature refrigeration chamber and shows the heat influx into the chamber. Table 1 shows the contribution of various heat inflows to the total heat input into the chamber. The thickness of the insulation in the redistribution from 80 to $120 \mathrm{~mm}$ is not so decisive factor affecting the required cooling capacity, as it may seem at first glance.

Table 1 - The contribution of various heat inflows to the thermal load on the equipment.

\begin{tabular}{|c|l|c|}
\hline \multicolumn{3}{|c|}{$\begin{array}{l}\text { Heat inflow to the cold room } \mathbf{6} \text { sq. m. The thickness of } \\
\text { the insulation of the chamber is } \mathbf{1 0 0} \mathbf{~ m m} .\end{array}$} \\
\hline № & \multicolumn{1}{|c|}{ Heat transfer } & $\mathbf{k W}$ \\
\hline 1. & Insulation structures & $0.589 \mathrm{~kW}$ \\
\hline 2. & $\begin{array}{l}\text { Equipment (defrosters, fans, } \\
\text { lighting) }\end{array}$ & $\begin{array}{c}0.290 \mathrm{~kW} \\
1.8 \mathrm{~kW}-\text { heater }\end{array}$ \\
\hline 3. & Heat input from open doors & $0,174 \mathrm{~kW}$ \\
\hline 4. & $\begin{array}{l}\text { Heat input from after-cooling } \\
\text { of products }\end{array}$ & $0.537 \mathrm{~kW}$ \\
\hline \multicolumn{2}{|c|}{ Total heat input } & $\mathbf{3 . 1} \mathbf{~ k W}$ \\
\hline
\end{tabular}




\section{Chamber cost price and influence of various} groups of materials on the final price of the chamber

Analyzing the cost of a typical refrigerating chamber, it is worthwhile to classify the materials used and examine the characteristics of each of the groups. Table 2 shows the decoding of the cost of the camera with an area of $6 \mathrm{~m}^{2}$, with a temperature in the cooled volume $-18 \ldots-22^{\circ} \mathrm{C}$.

Characterizing the heat exchange equipment, it should be noted that in typical schemes there is no recuperative heat exchanger. In some cases, this leads to the freezing of the compressor, however, as a rule, the customer, consciously, refuses this device. The second factor that influences the selection of equipment is the noise factor, a successful store is usually located in a residential area and is located either on the ground floor of a multi-storey residential building or in a detached building that is nevertheless still in close proximity to residential premises.

Table 2 - Estimated cost of the components of the cold store area of 6 square meters for 2017 year.

\begin{tabular}{|l|c|c|c|}
\hline \multicolumn{1}{|c|}{ Model } & Brands & Cost $€$ & \% \\
\hline $\begin{array}{l}\text { Heat exchanging } \\
\text { equipment }\end{array}$ & Guntner & 1288.98 & 36.6 \\
\hline Compressor & Tecumseh & 437.00 & 11.7 \\
\hline $\begin{array}{l}\text { Insulation } \\
\text { structures }\end{array}$ & - & 1065.75 & 28.4 \\
\hline Electrical part & Eaton & 364.80 & 9.8 \\
\hline $\begin{array}{l}\text { Hydraulic part } \\
\text { and automation }\end{array}$ & $\begin{array}{c}\text { Alco, } \\
\text { Danfoss, } \\
\text { Castel }\end{array}$ & 535.18 & 12.4 \\
\hline $\begin{array}{l}\text { Metal structures } \\
\text { and floors of the } \\
\text { refrigerating } \\
\text { chamber. }\end{array}$ & - & 43.35 & 1.1 \\
\hline Total & & $\mathbf{3 7 3 0 . 0 6}$ & $\mathbf{1 0 0}$ \\
\hline
\end{tabular}

The current legislation regulates the level of noise pollution according to the sanitary norms of permissible noise in the premises of residential and public buildings and on the territory and in the territory of residential buildings [1]. For territories directly adjacent to residential buildings for refrigeration, the maximum noise level from 07:00 to 23:00 should not exceed 70 DBA, from 23:00 to 07:00 - 60 DBA.

Table 3 - Comparative rise in price of capacitors in the transition to low-speed fans.

\begin{tabular}{|c|c|c|c|}
\hline Brand & Model & $\begin{array}{c}\text { Speed of } \\
\text { rotation } \\
\text { Rpm }\end{array}$ & $\begin{array}{c}\text { Cost } \\
€\end{array}$ \\
\hline Guntner & GVM 040.1C/1-LW.E & 910 & 482 \\
\hline Guntner & GCVC RD 035.1/12 & 910 & 532 \\
\hline $\begin{array}{c}\text { LLOUD } \\
\text { Ziehl- } \\
\text { Abegg }\end{array}$ & FN035.4EK.WD.V7 & 1310 & 143,0 \\
\hline $\begin{array}{c}\text { LLOUD } \\
\text { Ziehl- } \\
\text { Abegg }\end{array}$ & FN045.SDK.4F.V7P1 & 710 & 281 \\
\hline \multicolumn{2}{|l}{ SPR 14 } & 208 \\
\hline
\end{tabular}

As a result, the condenser should have slow-speed fans with a speed of 600 to $800 \mathrm{rpm}$, which results in an increase in the heat exchange surface and, accordingly, in cost. Nevertheless, it is worth noting that not always the speed in the specified range is characterized by the fan as slowmoving, always refer to the technical documentation. In the case of a significant increase in the ambient temperature, it is possible to replace the fan with a high-speed fan, even if the permissible noise levels are exceeded, a short-term application of a high-speed fan is quite practical. In the case of the transition from high-speed fans to slow-moving ones, we have the following dynamics of the rise in price for the main grades of heat-exchange equipment applicable in shop construction (for the construction of chambers see Table 3).

\section{Characteristics of main groups of complete refrigeration chambers applied in construction}

Considering the cost and features of the control panel, it is worth noting that at the moment the largest retail chains in Ukraine require the use of EATON brand control boards. This is due to the optimal ratio of the price and quality of these components. According to the rules for the operation of electrical installations (PUE), it is recommended to use a residual current device (RCD) for additional protection against electric shock in case of direct contact in refrigerating chambers [2]. A separate feature is the gradual rejection of resistive heaters for drainage of the evaporator and the cable for heating the doors in favor of self-adjusting ones. This is due to the higher reliability and ease of installation of the latter.

The hydraulic part and automation are represented exclusively by foreign components of such manufacturers as ALCO, DANFOSS and CASTEL. Electronic TEVs are currently only distributed in a number of large retail chains, small retail chains are not ready to invest in this direction at the moment.

An important feature is the design of the floor of the refrigerating chamber, proceeding from the requirements of universality, it is recommended to use insulated floors made of polyurethane foam board even in positive cameras. As a covering of a plate the possible variants, or the zinced sheet in the thickness not less than $0.7 \mathrm{~mm}$, aluminum corrugated floors in thickness of $1.5 \mathrm{~mm}$. Metal sheets up to $3 \mathrm{~mm}$ thick are also used. In each case, the choice of the floor design must be based on the operating conditions and customer's wishes, for example, thin galvanized floors are easily pierced by hydraulic trolleys, but at the same time are cheap and stand for a minimum of 4 to 5 years. In such cases it is recommended to additionally apply special plastic linings to protect the floors from damage.

Another factor that affects the final cost of cold rooms is the use of anti-vandal grills and boxes. Considering the cost of refrigeration equipment, in particular condensers and copper pipes, most customers require the laying of security. And in the case of copper pipes that pass outside the premises, at least their visual security is required. In this case, you should pay attention to the fact that the cost of manufacturing finished metal varies between 10 and 12 thousand UAH. For a ton of finished products and can in some cases give a significant rise in the cost of the camera as a whole. 
When calculating the cost of insulation is recommended to lay $10-15 \%$ of the additional area of insulation, which is due to the presence on the panels of locks and waste. As a rule, after the sweep, just such a quantity of the total area of the panels can not be used in the future.

Analyzing existing units, it is worth noting that most machines are not equipped with a recuperative heat exchanger, use R22 or R507 refrigerant. Structurally, these are usually units mounted on frames rigidly engaged to the floor.

A detailed cost analysis shows that almost all components are rigidly tied to the Euro rate, except for metal structures and insulation materials, which are less related to the currency component. As of the beginning of 2017, the cost of one camera, excluding transport costs and personnel salaries, is about 3,730.06 euros with VAT. The collapse of the hryvnia exchange rate in 2014-2016 has changed the cost of cold supply to a large extent. A significant rise in the price of electric energy is, to a very small extent, contributing to the introduction of energysaving technologies. The same applies to the minimum heat-exchange surface, and the most simple thermodynamic schemes. The use of heat of condensation as a source of secondary heat in the shop industry at the moment does not take place at all. Although in the case of linking all refrigeration equipment to one circuit under one central and one condenser, a good source of low-potential heat is created, which can be used both as a source of heating and hot water supply, and for defrosting refrigeration furniture. However, such circuit solutions require serious engineering calculations and highly qualified maintenance. It is worth noting that the current management scheme of most large retail chains assumes that absolutely different sectors of the technical departments are responsible for the cooling and heat supply, which largely hinders the implementation of energy conservation.

\section{Conclusions}

The cost of the refrigerating chamber is analyzed based on market prices for 2017. The price policy is acceptable for installation organizations. The contribution of various groups of components to the final cost of the camera is analyzed. Recommendations are given for designing refrigerating chambers for trade objects. The advantages and disadvantages of constructive solutions used in the construction of refrigerated chambers of commerce, currently used in Ukraine, are considered.

\section{References}

1. Правила устройства электроустановок [Текст]. ПУЭ. Издательство: «Индустрия» ISBN 978-966-2160-50-5, 2015 г. -768 c.

2. Санитарные норма допустимого шума в помещениях жилых и общественных зданий и на территории жилой застройки [Электронный ресурс]. - Режим доступа: http://zakon3.rada.gov.ua/laws/show/v7_84400-84

\title{
Особенности технико-экономических расчетов холодильных камер объектов торговли
}

\author{
М. Г. Хмельнюк, Д. И.Важинский, А. В. Остапенко
}

Одесская национальная академия пищевых технологий, ул. Канатная, 112, Одесса, 65039, Украина

\begin{abstract}
В современной Украине на объектах торговли получили распространение камеры небольшой вместимости от 4 $м^{2}$ до $11 м^{2}$. Причем, при увеличении площуади торгового зала увеличивается, как правило, количество камер, а не их вместимость. Использование центрального холодоснабжения имеет ограниченное применение распространение, это вызвано тем что большинство объектов торговли располагаются на площадях, которые изначально не проектировались под магазин. Не редки случаи, когда камеры добавляются уже после сдачи объекта. Данный фактор влияет на длину фреонопроводов, и сложность монтажа тем самым увеличивая капитальные затрата и усложняя монтажные работы. Стоит так же обратить внимание, что в случае выхода из строя холодильной централи, возникает необходимость в резервном холодоснабжении. Проектирование таких камер имеет специфику как с точки зрения теплового расчета, закладывание дополнительной холодопроизводительности для доохлаждения продукции, так и предполагает особые конструктивные требования, такие как, например, наличие антивандальных решеток. Особым фактором, влияюшим на цену камеры, являются фактор иумов как от работы компрессоров (в случае расположения агрегата не в помещении), так и конденсаторов, что сказывается на конечной стоимости. В конечном итоге, любой инженерный расчет имеет смысл только в контексте конечной стоимости, поэтому актуальной является именно себестоимость камеры, и влияние стоимости различных групп материалов на конечную стоимость камеры. В современной экономической ситуации, когда большинство корпораций и государственный сектор перешли на тендерную модель закупок грамотный технико-экономический расчет приобрёл особую актуальность
\end{abstract}

